\title{
Pengaruh Pemberian Latihan Soal Dengan Tuntunan Penyelesaian Dalam Pembelajaran Langsung Terhadap Peningkatan Pemahaman Konsep Hukum Perbandingan Tetap Pada Siswa Kelas X SMA Negeri 4 Palangka Raya Tahun Ajaran 2018/2019
}

\author{
Sela Anjelia \\ Program Studi Pendidikan Kimia, Jurusan Pendidikan MIPA, Fakultas Keguruan \\ dan Ilmu Pendidikan, Universitas Palangka Raya, Indonesia \\ E-mail: selaanjelia0103@gmail.com
}

Diterima: 14 Nopember 2020; Disetujui: 30 Nopember 2020; Diterbitkan: 2 Desember 2020

\begin{abstract}
ABSTRAK
Tujuan dari penelitian ini adalah untuk menjelaskan pengaruh pemberian tuntunan penyelesaian latihan soal dalam pembelajaran langsung terhadap pemahaman konsep hukum perbandingan tetap (Hukum Proust) pada Siswa Kelas X SMA Negeri 4 Kota Palangka Raya tahun ajaran 2018/2019. Jenis penelitian ini adalah penelitian kuantitatif. Peneliti melakukan eksperimen dengan menentukan sampel untuk kelas kontrol dan kelas eksperimen. Subjek penelitian adalah 71 siswa kelas X SMA Negeri 4 Kota Palangka Raya tahun ajaran 2018/2019. Instrumen yang digunakan berupa tes pemahaman konsep (tes I dan tes II) berbentuk esai berjumlah 4 soal dan latihan soal dengan tuntunan penyelesaian yang dikemas dalam bentuk lembar soal yang berisi langkah-langkah penyelesaian soal. Berdasarkan hasil uji statistik menggunakan uji-t menunjukkan bahwa terdapat perbedaan peningkatan pemahaman konsep hukum perbandingan tetap hasil pembelajaran menggunakan latihan soal dengan tuntunan penyelesaian dengan menggunakan latihan soal tanpa tuntunan penyelesaian pada siswa kelas $\mathrm{X}$ SMA Negeri 4 Palangka Raya. Rata-rata peningkatan pemahaman konsep pada ngain kelas eksperimen $(73,48 \%)$ lebih tinggi dari kelas kontrol $(54,57 \%)$.
\end{abstract}

Kata Kunci: Hukum Perbandingan Tetap, Pengaruh, Tuntunan

\section{PENDAHULUAN}

Antusiasme siswa dalam mengikuti pelajaran kimia di sekolah tidak seperti mengikuti pelajaran lainnya. Bagi siswa, konsep dan prinsip kimia menjadi sulit dipahami dan dicerna oleh kebanyakan mereka. Hal ini berdampak pada rendahnya minat siswa untuk belajar kimia. Masalah ini merupakan salah satu masalah klasik yang kerap dijumpai oleh para guru kimia di sekolah, ditambah pula dengan kebiasaan guru yang lebih sibuk memfokuskan pada siswa dengan rumus-rumus yang tidak mudah dipahami.

Ilmu kimia adalah salah satu bidang kajian yang termasuk dalam rumpun sains yang memiliki karakter tersendiri dan keterampilan dalam menyelesaikan masalah-masalah dalam kimia yang berupa teori, konsep, hukum dan fakta yang berhubungan dengan komposisi, sifat dan perubahan materi (Sudarmo, 2016).

Salah satu media yang dapat digunakan dalam pembelajaran di sekolah adalah LKS. Hasil penelitian (Santi, 2016), tentang hukum Proust mengungkapkan bahwa pemahaman konsep siswa setelah menggunakan LKS- 
penyelesaian soal terstruktur meningkat dari 15,9\% sebelum menggunakan LKSpenyelesaian soal terstruktur (saat pembelajaran langsung) menjadi 84,9\% setelah penggunaan LKSpenyelesaian soal terstruktur, oleh karena itu peneliti dapat menemukan cara yang tetap untuk mengatasi kesulitan siswa, yaitu dengan menggunakan LKS-penyelesaian soal terstruktur.

Hasil penelitian Grasina (2015) mengungkapkan terjadinya peningkatan pemahaman terhadap materi hukum Proust pasca pembelajaran menggunakan LKS dalam menghitung massa unsur yang bereaksi jika diketahui massa senyawa yang terbentuk dari hasil reaksi yaitu meningkat sebesar $72 \%$ dari nilai rata-rata pretes sebesar $16 \%$ menjadi $88 \%$ saat postes.

Berdasarkan uraian diatas, perlu dikaji apakah pemberian tuntunan penyelesaian latihan soal efektif untuk meningkatkan pemahaman konsep pada materi hukum perbandingan tetap (hukum Proust), sehingga peneliti ingin mengkaji penelitian dengan judul pengaruh pemberian tuntunan penyelesaian latihan soal dalam pembelajaran langsung terhadap pemahaman konsep hukum perbandingan tetap (Hukum Proust) pada siswa kelas X SMA Negeri 4 Palangka Raya tahun ajaran 2018/2019.

Rumusan masalah pada penelitian ini yaitu apakah terdapat perbedaan pengaruh pemberian latihan soal yang dilengkapi tuntunan penyelesaian dan latihan soal tanpa tuntunan penyelesaian dalam pembelajaran langsung terhadap peningkatan pemahaman konsep hukum perbandingan tetap pada siswa kelas $\mathrm{X}$ SMA Negeri 4 Palangka Raya tahun ajaran 2018/2019.

Tujuan penelitian ini adalah untuk menjelaskan perbedaan pengaruh pemberian latihan soal yang dilengkapi tuntunan penyelesaian dan latihan soal tanpa tuntunan penyelesaian dalam pembelajaran langsung terhadap peningkatan pemahaman konsep hukum perbandingan tetap (Hukum Proust) pada siswa kelas X SMA Negeri 4 Palangka Raya tahun ajaran 2018/2019.

\section{METODE PENELITIAN}

Jenis penelitian yang digunakan dalam penelitian ini adalah penelitian kuantitatif. Penelitian ini terbagi dalam dua kelas yaitu kelas eksperimen dan kelas kontrol. Kelompok eksperimen adalah kelas sampel yang diberikan perlakuan khusus yaitu dengan tuntunan latihan soal dalam pembelajaran langsung, sedangkan pada kelas kontrol adalah kelas sampel yang digunakan sebagai perbandingan yaitu tanpa tuntunan latihan soal dalam pembelajaran langsung.

Metode penelitian yang digunakan dalam penelitian ini adalah metode quasi eksperiment karena mempunyai kelompok kontrol yang dapat membantu proses penelitian, akan tetapi tidak berfungsi sepenuhnya karena untuk mengontrol variabel-variabel luar yang masih mempengaruhi pelaksanaan eksperimen. Penelitian ini pada kelas eksperimen mendapatkan perlakuan khusus sedangkan kelas kontrol tidak mendapatkan perlakuan khusus. Penelitian ini kelas eksperimen diberikan tuntunan penyelesaian latihan soal sedangkan kelas kontrol diberikan latihan soal tanpa tuntunan penyelesaian.

Teknik pengambilan sampel pada penelitian ini adalah cluster random sampling. Dalam teknik sampling ini, populasi dibagi menjadi beberapa kelompok atau cluster. Data yang diperlukan dalam penelitian ini adalah data kuantitatif berupa skor hasil tes belajar siswa kelas X MIA semester II SMA Negeri 4 Palangka Raya tahun ajaran 2018/2019 dalam menyelesaikan soal konsep hukum 
perbandingan tetap. Teknik pengumpulan data yang digunakan dalam penelitian ini berupa tes uraian, tahap-tahap yang digunakan dalam pengumpulan, yaitu: Tahap I, tahap ini kedua sampel (kelas kontrol dan kelas eksperimen) diberikan materi dengan metode pembelajaran langsung. Selanjutnya, diberikan tes I untuk mengetahui dan mengukur kemampuan awal siswa terhadap materi pelajaran yang akan diberikan pada saat perlakuan. Tahap II, tahap ini, kelas yang berperan sebagai kelas eksperimen diberikan latihan soal dengan tuntunan penyelesaian saat proses pembelajaran. Sementara kelas kontrol diberikan latihan soal yang tidak berisi tuntunan cara mengerjakan seperti halnya latihan soal untuk kelas eksperimen. Tahap III, tahap terakhir ini merupakan tahap pengukuran penguasaan materi oleh siswa. Pengukuran ini diberikan dengan pemberian tes II pada masing-masing kelas. Data yang diperoleh kemudian dianalisis dengan teknik analisis data pada penelitian ini.

Berikut tahap-tahap pengolahan data yang diperoleh dari lembar jawaban siswa tes I dan tes II: Pensekoran Jawaban Siswa, pemeriksaan hasil tes setiap siswa dilakukan dengan memberi skor pada lembar jawaban tes I dan lembar jawaban tes II. Menjumlahkan skor yang diperoleh masing-masing siswa dan mengkonversikan dalam bentuk nilai dengan rumus sebagai berikut:

Persentase pemahaman konsep untuk setiap siswa:

$$
\rho=\frac{\sum \text { skor yang diperoleh siswa }}{\sum \text { skor maksimum }} \times 100 \%
$$

Rata-rata dihitung, nilai yang diperoleh setiap kelas dengan rumus berikut:

$\bar{x}=\frac{1}{n} \sum_{i=1}^{n} \mathrm{x}_{i}$ Menentukan rata-rata nilai yang diperoleh pada setiap indikator dengan rumus berikut:

nilai rata-rata indikator $=\frac{\sum \text { jumlah skor pada indikator }}{\sum(\text { jumlah siswa }) \cdot(\text { skor maksimal indikator })} \times 100 \%$

Sebaran data ditunjukkan yang meliputi langkah-langah sebagai berikut: Kelas Interval, dimasukkan data bernilai mulai dari a sampai dengan b yang diketahui rata-rata dan standar deviasi. Adapun rumus untuk menentukan kelas interval yaitu: $\mathrm{R}=$ nilai tertinggi-nilai terendah

$$
\begin{gathered}
\mathrm{K}=1+3,3 \log \mathrm{n} \\
\mathrm{I}=\frac{R}{K}
\end{gathered}
$$

Ditentukan banyak data pada setiap kelas interval yaitu frekuensi $(\mathrm{F})$, dan Frekuensi Kumulatif (FK) yang merupakan penjumlahan (kurang dari) atau pengurangan (lebih dari) frekuensi dari setiap kelas interval, sehingga jumlah frekuensi terakhrir berjumlah sama dengan jumlah data untuk distribusi frekuensi kumulatif kurang dari dan jumlah frekuensi terakhir 0 untuk distribusi frekuensi lebih dari.

$\mathrm{N}$-gain score dihitung dengan menggunakan rumus: $\mathrm{N}$-Gain $=\frac{S_{2}-S_{1}}{S_{\max }-S_{1}}$

Keterangan: $\mathrm{S}_{1}=$ Skor Tes I

$\mathrm{S}_{2}=$ Skor Tes II

$\mathrm{S}_{\max }=$ Skor maksimum yang diperoleh siswa

Uji normalitas dimaksudkan untuk menguji normal atau tidaknya distribusi data pada sampel. Uji normalitas ini menggunakan cara SPSS 25 untuk menghitung uji normalitas n-gain pada kelas eksperimen dan kelas kontrol, dengan tujuan untuk mengetahui distribusi data yang akan diperoleh dari tes masing-masing kelas siswa tersebut. 
Dasar keputusan uji Normalitas shapiro-wilk.

Jika nilai sig. > 0,05 maka data berdistribusi normal.

Jika nilai sig. $<0,05$ maka data tidak berdistribusi normal.

Uji homogenitas digunakan untuk menguji apakah populasi penelitian mempunyai varian yang sama. Varian merupakan jumlah kuadrat semua deviasi nilai-nilai individual terhadap rata-rata kelompok.

Masing-masing kelompok dihitung nilai variannya $\left(S^{2}{ }_{1}\right.$ dan $\left.S_{2}^{2}\right)$, setelah didapatkan nilai $S^{2}{ }_{1}$ dan $S_{2}^{2}$, pengujian homogenitas varian menggunakan uji $\mathrm{F}$ dengan rumus sebagai berikut:

di mana: $\mathrm{F}=$ koefisien $\mathrm{F}$ tes

$$
F=\frac{\text { varian terbesar }}{\text { varian terkecil }}
$$

Kriteria pengujian adalah membandingkan harga $F_{\text {hitung }}$ dengan $F_{\text {tabel }}$ pada taraf signifikan $5 \%$ dengan dk pembilang dan penyebut $=\mathrm{n}_{1}-1$ yaitu:

- $\quad$ Jika harga $F_{\text {hitung }} \leq \mathrm{F}_{\text {tabel }}$ maka data tersebut homogen.

- Jika harga $F_{\text {hitung }}>F_{\text {tabel }}$ maka data tersebut tidak homogen.

Hipotesis merupakan jawaban sementara terhadap rumusan masalah penelitian. Terdapat 2 macam hipotesis statistik dalam penelitian ini yaitu hipotesis nol $\left(\mathrm{H}_{0}\right)$ dan hipotesis kerja $\left(\mathrm{H}_{\mathrm{a}}\right)$ yang berbunyi:

$\mathrm{H}_{0}\left(\mu_{1}=\mu_{2}\right)$ : Tidak terdapat perbedaan pengaruh pemberian latihan soal yang dilengkapi tuntunan penyelesaian dengan latihan soal tanpa tuntunan penyelesaian dalam pembelajaran langsung terhadap peningkatan pemahaman konsep hukum perbandingan tetap pada siswa kelas $\mathrm{X}$ SMA Negeri 4 Palangka Raya tahun ajaran 2018/2019.

Ha $\left(\mu_{1} \neq \mu_{2}\right)$ : Terdapat perbedaan pengaruh pemberian latihan soal yang dilengkapi tuntunan penyelesaian dengan latihan soal tanpa tuntunan penyelesaian dalam pembelajaran langsung terhadap peningkatan pemahaman konsep hukum perbandingan tetap pada siswa kelas $\mathrm{X}$ SMA Negeri 4 Palangka Raya tahun ajaran 2018/2019.

Di mana:

$$
\begin{aligned}
& \mathrm{H}_{0}: \mu_{1}=\mu_{2} \\
& \mathrm{H}_{\mathrm{a}}: \mu_{1} \neq \mu_{2}
\end{aligned}
$$

$\mu_{1}=$ Rata-rata nilai pemahaman konsep siswa pada materi hukum perbandingan tetap hasil pembelajaran menggunakan latihan soal dengan tuntunan penyelesaian

$\mu_{2}=$ Rata-rata nilai pemahaman konsep siswa pada materi hukum perbandingan tetap hasil pembelajaran menggunakan latihan soal tanpa tuntunan

Untuk menguji hipotesis tersebut digunakan uji-t, rumus uji-t yang digunakan adalah sebagai berikut:

$$
\mathrm{t}=\frac{\bar{X}_{e}-\bar{X}_{k}}{\sqrt{\frac{\left(n_{e}-1\right) s_{e}^{2}+\left(n_{k}-1\right) s_{k}^{2}}{n_{e}+n_{k}-2}\left(\frac{1}{n_{k}}+\frac{1}{n_{e}}\right)}}
$$

Dengan kriteria pengujian berlaku adalah:

- $\quad$ Jika $t_{\text {hitung }}>\mathrm{t}_{\text {tabel }}$ dengan taraf signifikan $5 \%$ dan $\mathrm{db}=\mathrm{n}-1$ maka $\mathrm{H}_{0}$ ditolak $\mathrm{H}_{\mathrm{a}}$ diterima

- Jika sebaliknya yakni $t_{\text {hitung }} \leq t_{\text {tabel }}$ maka $H_{0}$ diterima $H_{a}$ ditolak

\section{HASIL PENELITIAN DAN PEMBAHASAN}


Hal penting dalam pelaksanaan pembelajaran adalah terlebih dahulu dilakukannya simulasi. Simulasi bertujuan untuk melihat keterlaksanaan waktu dan keterbacaan soal serta hal-hal lain yang dianggap perlu akan menjamin keterlaksanaan tahapan pembelajaran yang benar dan keterbacaan siswa dengan menggunakan latihan soal. Data nilai tes I diperoleh setelah pembelajaran langsung dan data tes II diperoleh setelah pembelajaran menggunakan pemberian tuntunan penyelesaian latihan soal. Data tes I dimaksudkan untuk mengetahui pemahaman konsep siswa setelah mengikuti pembelajaran langsung sedangkan data nilai tes II digunakan untuk mengetahui hasil perlakuan yang diberikan. Data soal tes II juga digunakan untuk mengetahui pengaruh penggunakan latihan soal dengan pemberian tuntunan penyelesaian terhadap pemahaman siswa.

Keterbacaan yang dimaksud adalah redaksi kalimat yang terdapat di dalam instrumen penelitian yang dibuat oleh peneliti cukup dipahami oleh siswa, baik mengenai instruksi atau pedoman pengisian dan butir-butir pertanyaan. Simulasi tersebut meliputi pelaksanaan pembelajaran yang akan diteliti, yaitu dimulai dari tahap pembelajaran langsung dengan metode ceramah, tes I lal pembelajaran menggunakan pemberian tuntunan penyelesaian latihan soal, dan tes II yang melibatkan 36 siswa kelas X-2 sebagai kelas eksperimen. Tahap pembelajaran langsung dengan metode ceramah, tes I pembelajaran menggunakan latihan soal tanpa tuntunan penyelesaian dan tes II yang melibatkan 35 siswa kelas X-4 sebagai kelas kontrol. Simulasi pembelajaran dilaksanakan pada tanggal 23 Mei 2019 yang melibatkan 71 siswa kelas X SMA Negeri 4 Palangka Raya.

Data nilai tes I diperoleh setelah pembelajaran langsung dan data tes II diperoleh setelah pembelajaran menggunakan pemberian tuntunan penyelesaian latihan soal. Data tes I dimaksudkan untuk mengetahui pemahaman konsep siswa setelah mengikuti pembelajaran langsung sedangkan data nilai tes II digunakan untuk mengetahui hasil perlakuan yang diberikan. Data soal tes II juga digunakan untuk mengetahui pengaruh penggunakan latihan soal dengan pemberian tuntunan penyelesaian terhadap pemahaman siswa.

Data tes I kelas eksperimen diperoleh setelah pelaksanaan pembelajaran langsung yang diikuti 36 orang siswa dengan nilai terendah 25 dan nilai tertinggi 83,33 dengan mean sebesar 35,65 dan standar deviasi 15,31. Data nilai tes II diperoleh setelah pembelajaran menggunakan lembar kerja pemberian tuntunan penyelesaian latihan soal dengan nilai terendah 41,67 dan nilai tertinggi 100 . Mean nilai tes II sebesar 81,94 dan standar deviasi adalah 12,03.

Data nilai tes I diperoleh setelah di lakasanakan pembelajaran langsung dan data tes II diperoleh setelah pelaksanaan pembelajaran menggunakan lembar kerja latihan soal. Data tes I dimaksudkan untuk mengetahui pemahaman konsep siswa setelah mengikuti pembelajaran langsung sedangkan data nilai tes II digunakan untuk mengetahui hasil perlakuan yang diberikan. Data soal tes II juga digunakan untuk mengetahui pengaruh penggunaan latihan soal tanpa tuntunan penyelesaian terhadap pemahaman siswa.

Data nilai tes I kelas kontrol diperoleh nilai terendah 25 dan nilai tertinggi 83,33 dengan rata-rata 35,24 dan standar devisi 15,72. Data nilai tes II memiliki nilai terendah 41,67 dan nilai tertinggi 100 dengan nilai rata-rata 70,48 dan standar deviasi adalah 14,2 .

Uji normalitas bertujuan untuk mengetahui apakah nilai n-gain kelas eksperimen dan kelas kontrol yang diperoleh dalam penelitian berdistribusi 
normal atau tidak. Peneliti menghitung dengan cara menggunakan SPSS. Hasil perhitungan uji normalitas n-gain yang menunjukkan kelas eksperimen dan kelas kontrol yaitu sig $>\alpha_{(0,05)}$. Dapat disimpulkan bahwa data n-gain kelas eksperimen dan kontrol berdistribusi normal.

Uji homogenitas ini bertujuan untuk mengetahui apakah nilai n-gain kelas eksperimen dan kelas kontrol mempunyai varian yang homogen atau tidak. Uji homogenitas ini menggunakan rumus Fisher $(\mathrm{F})$. Kriterian pengujian adalah membandingkan $\mathrm{F}_{\text {hitung }}$ dengan $\mathrm{F}_{\text {tabel }}$ pada signifikan 5\% dengan derajat kebebasan (n-1). Berdasarkan hasil perhitungan dari data kelas eksperimen dan kelas kontrol didapatkan $\mathrm{F}_{\text {hitung }}=1,55$ sedangkan $\mathrm{F}_{\text {tabel }}=1,79$ (Perhitungan lengkap dapat dilihat pada Lampiran 14), karena $F_{\text {hitung }}<F_{\text {tabel }}$ maka dapat disimpulkan bahwa data tes awal pada kelas eksperimen dan kelas kontrol dinyatakan homogen.

Data yang diperoleh menunjukkan bahwa rata-rata data nilai tes pada kelas eksperimen adalah sebesar 73,48 dan pada kelas kontrol adalah 54,57. Data yang diperoleh kemudian diolah menggunakan SPSS 25 untuk menunjukkan nilai signifikansi n-gain kedua kelas sampel. Nilai signifikansi diperoleh dengan uji analisis Shapiro-Wilk, dengan signifikansi 0,10 untuk kelas eksperimen dan signifikansi 0,35 untuk kelas kontrol. Berdasarkan perhitungan uji-t untuk data nilai tes kelas eksperimen dan kelas kontrol diperoleh $t_{\text {hitung }}$ sebesar 2,79 sedangkan $t_{\text {tabel }}$ dengan $\mathrm{db}=\mathrm{n}_{1}+\mathrm{n}_{2}-2=69$ taraf signifikan 5\% sebesar 1,67 (perhitungan ada pada Lampiran ). Jadi, $t_{\text {hitung }}>t_{\text {tabel }}$ maka, $\mathrm{H}_{0}$ ditolak dan $\mathrm{H}_{\mathrm{a}}$ diterima, dengan demikian dapat disimpulkan bahwa terdapat perbedaan peningkatan pemahaman konsep hukum perbandingan tetap hasil pembelajaran menggunakan latihan soal dengan tuntunan penyelesaian juga menggunakan latihan soal tanpa tuntunan penyelesaian pada siswa kelas X SMA Negeri 4 Palangka Raya.

Pemahaman konsep siswa terhadap materi hukum perbandingan tetap pada kelas eksperimen dan kelas kontrol dianalisis berdasarkan skor tes I dan tes II setiap indikator dan tujuan pembelajaran. Jawaban siswa yang dianalisis adalah siswa pada kelompok atas dan kelompok bawah kelas eksperimen maupun kelas kontrol hal ini dilakukan untuk mempermudah dalam membandingan pengaruh pada kedua kelas tersebut. Siswa yang tergolong kelompok atas atau kelompok bawah diperoleh dari wawancara kepada guru SMA Negeri 4 Palangka Raya berdasarkan hasil nilai UTS. Jumlah siswa yang dilibatkan dalam penelitian ini lebih dari 30 siswa, kemudian diambil masing-masing sebanyak 27\% dari kelompok atas dan kelompok bawah untuk keperluan analisis. Berdasarkan perhitungan, jumlah siswa yang termasuk kelompok atas dan kelompok bawah kelas eksperimen maupun kelas kontrol masing-masing berjumlah 9 siswa. Berikut ini analisis pemahaman konsep siswa pada setiap indikator.

Pemahaman konsep siswa dalam menentukan perbandingan massa unsur dalam senyawa berdasarkan data percobaan ditelusuri menggunakan butir soal 1 dengan skor maksimal 2.

Jawaban siswa pada tes I dan tes II, mencerminkan pemahaman atau kemampuan siswa dalam menghitung massa zat yang bereaksi, massa zat yang terbentuk dan massa zat yang tersisa diberi skor dengan rentang 0 sampai 4 .

Pemahaman siswa dalam menentukan massa unsur dalam senyawa jika diketahui perbandingan massa unsur ditelusuri menggunakan butir soal nomor 3 . 
Skor jawaban tes I dan tes II menunjukkan pemahaman siswa dengan kriteria penilaian untuk tes I dan tes II adalah sama.

Pemahaman siswa dalam menentukan persen massa unsur dalam senyawa jika diketahui perbandingan massa unsur ditelususri menggunakan butir soal nomor 4 dengan skor maksimum adalah 3. Skor jawaban tes I dan tes II menunjukkan pemahaman siswa dengan kriteria penilaian untuk tes I dan tes II adalah sama.

\section{KESIMPULAN DAN SARAN}

Berdasarkan hasil uji statistik menggunakan uji-t menunjukkan bahwa terdapat perbedaan peningkatan pemahaman konsep hukum perbandingan tetap hasil pembelajaran menggunakan latihan soal dengan tuntunan penyelesaian menggunakan latihan soal tanpa tuntunan penyelesaian pada siswa kelas X SMA Negeri 4 Palangka Raya. Rata-rata peningkatan pemahaman konsep pada n-gain kelas eksperimen $(73,48 \%)$ lebih tinggi dari kelas kontrol $(54,57 \%)$.

Berdasarkan hasil penelitian, disarankan bahwa pembelajaran langsung menggunakan pemberian tuntunan penyelesaian latihan soal pada pembelajaran kimia, khususnya pada materi yang bersifat penyelesaian dengan perhitungan dapat dijadikan alternatif pilihan untuk meningkatkan pemahaman konsep siswa.

\section{DAFTAR PUSTAKA}

Amalia, F. 2018. Pengaruh Penggunaan LKS-Latihan Soal Terstuktur Terhadap Peningkatan Pemahaman Konsep pH Larutan Penyangga Asam pada Siswa Kelas XI SMAN 4 Palangka Raya Tahun Ajaran 2017/2018. Skripsi Sarjana, Tidak Diterbitkan, Universitas Palangka Raya.

Arends, R. 1997. Classroom Instructional Management. NewYork: The Mc Graw-Hill Company.

Arifin, M., dkk. (2003) Strategi Belajara dan Mengajar Kimia Common Textbook. (Edisi Revisi). Bandung: Jurusan Pendidikan Kimia FPMIPA UPI.

Arikunto, S. 2006. Prosedur Penelitian: Suatu pendekatan Praktik. Jakarta: Rineka Cipta

Ferdinand, Augusty. 2006. Metode Penelitian Manajemen: Pedoman Penelitian untuk Skripsi, Tesis, dan Disertsi Ilmu Manajemen. Semarang: Universitas Diponegoro.

Dahar., Wilis, R. 1989. Teori-teori Belajar. Jakarta: Erlangga.

Dahar., Wilis, R. 2011. Teori-teori Belajar dan Pembelajaran. Jakarta: Erlangga.

Depdiknas. 2004. Pedoman Umum Pengembangan Bahan Ajar. Diunduh pada tanggal 14 april $2015 \mathrm{http} / \mathrm{www}$.pedomanumumpengembanganbahan ajar.ac.id/2004/07/pengertian-LKS.html Emzir.

Gagne, R.M. 1997. The Conditions of Learning. New York: Holt Rinehart and Wiston.

Holyni, A.G. 2015. Pemahaman Konsep Hukum Perbandingan Tetap (Hukum Proust) Pasca Penerapan Pembelajaran dengan Metode Resitasi Berbantuan LKS pada Siswa Kelas X.C SMAN 1 Pangkalan Banteng Tahun Ajaran 2014/2015. Skripsi Sarjana, Tidak Diterbitkan, Universitas palangka Raya.

Kardi, S., Nur, M. 2000. Pengajaran Langsung. Surabaya: University Press. 
Meyasi, Y. 2016. Kesulitan Siswa Kelas X SMA Negeri 1 Murung dan SMA Negeri 1 Gunung Timang Tahun Ajaran 2014/2015 dalam Memahami Hukum-hukum Dasar Kimia. Skripsi Sarjana, tidak diterbitkan. Universitas Palangka Raya.

Nazir, M. 1983. Metode Penelitian. PT. Bandung: Ghalia Indonesia

Prastowo, A. 2011. Panduak Kreatif Membuat Bahan Ajar Inofatif. Yogyakarta: Diva press.

Prethama, A. 2013. Analisis Pemahaman Konsep Persamaan Reaksi Kimia Pasca Pembelajaran Menggunakan LKS Latihan Soal Terstruktur pada Siswa Kelas X SMA Isen Mulang Palangka RayaTahun Ajaran 2013/2014. Skripsi Sarjana, tidak diterbitkan, Universitas Palangka Raya.

Raharjo, S. 2019. Cara Uji T Independent untuk N-gain Score dengan SPSS Lengkap dari http://youtube.be/rc0U0o7_uy8 Diakses Pada 27 Mei 2019.

Rossi dan Breidle. 1966. Perencanaan dan Desain System Pembelajaran. Jakarta: Kencana

Sanjaya, W. 2013. Penelitian Pendidikan, Jenis, Metode, dan Prosedur. Jakarta: Kencana Prenada Media Group.

Santi, D. P. 2016. Peningkatan Pemahaman Konsep Hukum Proust Pasca Penggunaan LKS-Penyelesaian Soal Terstruktur pada Pembelajaran di Kelas X SMA Negeri 1 Dusun Hilir Barito Selatan Tahun Ajaran 2015/2016. ISarjana Skripsi, tidak diterbitkan, Universitas Palangka Raya.

Sudarmo, U. 2016. Kimia untuk SMA/MA Kelas X. Jakarta: Erlangga

Sudjana, N. 2009. Peniliaian Hasil Proses Belajar Mengajar. Bandung: PT remaja Rosdakarya

Sugiyono. 2010. Metode Penelitian Pendidikan. Bandung: Alfabeta

Suyono dan Hariyanto. 2012. Belajar dan Pembelajaran. Bandung: PT Remaja Rosdakarya

Winkel, W.S. 1996, Psikologi Pendidikan, Jakarta: Gramedia. 